\title{
ARTICLES
}

Submitted 20.12.2016. Approved 25.09.2017.

Evaluated by double blind review process.

Scientific Editors: Ernesto Gonzalez and Charbel Jabbour

DOI: http://dx.doi/10.12660/joscmv10n2p85-99

\section{THE INFLUENCE OF TRIPLE BOTTOM LINE ON INTERNATIONAL OPERATIONS MANAGEMENT}

\begin{abstract}
This paper takes a triple bottom line perspective to analyze how the international operations literature integrates economic, social, and environmental issues. Additionally, it shows the main drivers of and barriers to the adoption of triple bottom line practices by companies in an international context. We conducted a literature review in English language journals which publish research of production and operations management and sustainability, resulting in a final sample of 29 papers. Results show that social and legal pressure for companies to adopt a responsible behavior prompts an isomorphic process that leads them to conduct their operations on behalf of triple bottom line goals. Behavioral differences between spin-offs in various countries caused institutions to create mechanisms that can press and change private standards through regulation and enforcement. There is room for progress in studies that seek to analyze the company's relationships in its international experience and its multi-institutional relations.
\end{abstract}

KEYWORDS | Triple bottom line, international operations management, sustainable operations, legal and social pressure, literature review.

\section{Francisco Sperotto Flores}

francisco.flores@iffarroupilha.edu.br

Director of Research, Extension and Production at Instituto Federal Farroupilha - Santo Augusto - RS, Brazil

luri Gavronski

igavronski@unisinos.br

Professor at Universidade do Vale do Rio dos Sinos, Centro de Ciências Econômicas - São Leopoldo - RS, Brazil

Vinicius Nardi

nardiadvocacia@gmail.com

PhD Student at Universidade do Vale do Rio dos Sinos - São Leopoldo - RS, Brazil

\section{Roselei Haag}

roseleihaag@gmail.com

PhD Student at Universidade do Vale do Rio dos Sinos - São Leopoldo - RS, Brazil 


\section{INTRODUCTION}

In the $20^{\text {th }}$ century, a series of environmental and social events raised awareness about the influence of business activities on social inequalities and environmental change. The media continuously stressed the impacts of every human endeavor by informing consumers and governments about their purchase practices, making society increasingly aware of sustainable issues.

The risk of irreversible damage to ecological systems, as well the exposition of exploitative labor practices in global supply chains, have put governments and companies under pressure to establish new environmental and labor regulations (Gavronski, 2012). To secure their business interests and protect the common good in the long-term, companies introduce a broad spectrum of management systems and technologies that can reduce environmental impacts and improve social performance (Wagner, 2015).

The greater attention that businesses have been paying to sustainability has led to an increase in the number of publications on the topic in the business and economics literature since the 1990's. In a search on Web of Science about "sustainability," we identified more than 7,000 articles published since 1994 and more than 70,000 citations. According to Carter and Rogers (2008), the most used definition of sustainability in this context is the one presented by the Brundtland Commission: "development that meets the needs of the present without compromising the ability of future generations to meet their own needs" (Wced, 1987, p. 8). This definition expresses the concern with issues such as understanding the environmental impact of economic activity and meeting basic human needs. However, they provide little guidance regarding how to identify present and future needs and operationalize sustainability (Carter \& Rogers, 2008; Hart, 1995; Meehan \& Bryde, 2011).

To operationalize sustainability, John Elkington presents, in his book Cannibals with Forks: The Triple Bottom Line of 21 $1^{\text {st }}$ Century Business, the concept of triple bottom line (3BL). The idea assumes that a business is sustainable when it balances economic, environmental and social goals, i.e., when its organizational activities can positively affect the natural environment and society and simultaneously result in economic benefits and competitive advantage (Carter \& Rogers, 2008; Norman \& MacDonald, 2004). This approach makes the implementation of sustainability complex, but prevents companies from focusing on a single issue, like economic performance, noting that businesses' long-term success depends on their ability to make decisions considering the impacts of economic, environmental and social aspects (Ferrer, 2008).

The assumption that companies should measure performance considering local communities plays a vital role in fostering sustainability, which is acknowledged over global manufacturing networks (Golini, Longoni, \& Cagliano, 2014). International operations management can affect these companies' financial performance and image around the world. They need to adjust their productive activities to the demands for sustainable operations in each target market by means of human rights, labor standards and environmental practices in a global context. Thus, integrating ecological and social issues and their financial objectives becomes one of their biggest challenges (Seuring \& Müller, 2008).

However, the corporate response has been neither strategic nor operational, but, rather, a cosmetic one, with philanthropic initiatives typically described in terms of money spent or voluntary work activities. They hardly ever consider the impact of productive activities on local communities or the natural environment (Porter \& Kramer, 2006).

Despite the increasing managerial and research interest in reaching a balance between the economic, environmental, and social goals of business activities, and the existing systems to operationalize sustainability in an international operations context, in-depth analyses of this research field are still to be conducted. There are a few literature reviews about sustainability issues in international operations management studies. However, Pisani et al. (2017) and Egri and Ralston (Egri \& Ralston, 2008) questioned the international nature of these studies. There is a lack of attention concerning operations in a transnational scenario, particularly in developing countries and regions. Moreover, these studies fail to balance 3BL goals, focusing instead on environmental and economic aspects (Khalid et al., 2015) academics are applying theory to explain these projects. The need for integrating the BoP population into value-adding activities is widely acknowledged, but this is not yet reflected in supply chain management (SCM, evidencing the gap between the concept of 3BL and its implementation in international operations studies. 
This paper aims to analyze how the international operations literature integrates Elkington's 3BL dimensions, and identify the main drivers and barriers to companies adopt 3BL practices in an international context. We conducted a literature review in English language journals which publish research of production and operations management and sustainability since 1997, resulting in a final sample of 29 papers. The study filtered only publications that balance social, environmental and economic aspects in an international operations scenario, disregarding papers that do not integrate all 3BL dimensions or with analyses performed only in a local scenario. The structure of this paper is as follows. First, we present the theoretical background. Next, we introduce the research method. Then, we expound the main findings of our literature review, i.e., the necessary social pressure and isomorphic change to integrate 3BL aspects into an international operations context, an analysis of the legislation and political demands related to this integration process; we also identify and examine the methodological approaches of the research included in our study. Finally, we conclude with a discussion of our findings and suggest opportunities of research.

\section{THEORETICAL BACKGROUND}

Traditionally, operations management is defined as the area that deals with the input, processing, and output of firm resources, i.e., the designing and management of processes, services, products and supply chains in order to produce goods and services. The literature of operations management provides tools to improve business processes and organization structures so as to create the highest possible value at the lowest possible cost (Kleindorfer, Singhal, \& Wassenhove, 2005).

In the last two decades, the business environment changed considerably. Businesses became more and more internationalized, while concerns with environmental and social issues have increasingly influenced operations management. The perception that the current production model compromises the planet's sustainable future has gained prominence in the public debate. The focus of Operations Management thus shifts from competition between firms to competition between supply chains. Companies need to improve their ability to establish close, longterm relationships with suppliers and other strategic partners to create value and achieve a competitive advantage in a context of global competition (Andersen \& Skjoett-Larsen, 2009).
Global supply chains need to manage cultural differences between suppliers across the globe, provide resources required by low-income suppliers in emerging markets, and respond to pressure by consumers and lawmakers in developed nations for better environmental and labor practices. Stakeholders' concerns become more and more relevant in lawmaking agendas, forcing politicians and governments to enhance labor and environmental policy's effectiveness (Hopkins et al., 2009). In addition, they indicate that a new attitude is necessary on the part of manufactures about the financial and social benefits of environmental improvements in productive processes (Abdala \& Barbieri, 2014; Nelson, Marsillac, \& Rao, 2012).

The new challenges in the business environment caused some articles to propose ways of operationalizing the concept of sustainability in international operations management. Although there are several approaches, the main concept in use in this task is the 3BL approach (Seuring \& Müller, 2008).

The idea of 3BL emerged from the perception that financial sustainability is not a sufficient condition to business sustainability (Dyllick \& Hockerts, 2002), and that the responsibilities of companies involve more than producing profitable goods and services (Hubbard, 2009). "The idea behind the 3BL paradigm is that a corporation's ultimate success or health can and should be measured not just by the traditional financial bottom line, but also by its social/ethical and environmental performance" (Norman \& MacDonald, 2004, p. 243). Environmental performance refers to certain resources a firm can use in its operations, while social performance reflects the firm's impact on the communities it operates in (Hubbard, 2009).

We consider 3BL a balance between the economic, ecological and social aspects of the company's activities. Carter and Rogers (2008) say that firms which can balance their social, environmental and economic performance are able to engage in activities that positively influence the natural environment and society while creating long-term economic benefits and competitive advantages for the firm. However, Tang and Zhou (2012) pointed out that such balance can only be achieved in the long run when the company sustains the economic, environmental and social flows for their entire supply chain, considering the needs of low-income suppliers in emerging markets, the supply chain's global markets, consumers in developed countries and the natural environment. 
The most problematic aspect of achieving this balance is designing a set of performance measures that can accurately reflect the organization's progress towards 3BL in a cross-national scenario (Ferrer, 2008). The multiple dimensions of performance implicit in the management of sustainable global supply chains increase the complexity of sustainability-oriented decisions. Here, stakeholders may play a role in management decision-making, in issues such as supplier selection or development. Thus, sustainable decisions become dependent on the relationship between stakeholders and the companies or supply chains (Sarkis \& Dhavale, 2015). The contemporary context of global supply chains make it necessary for both theorists and practitioners to observe other elements than the financial aspect. Therefore, the 3BL approach can provide a complete view of the phenomenon.

\section{METHODS}

We conducted a literature review that was limited to papers published in English in academic journals concerning the relationship between the Elkington's 3BL dimensions and international operations management. This method allows researchers to consolidate and evaluate the state of the art in a given topic, identifying research gaps and generating new interpretations of current knowledge (Seuring \& Gold, 2012; Tranfield, Denyer, \& Smart, 2003).

Our search was limited to 1997, year of publication of Ellington's book. We conducted the entire data collection process in the Web of Science database as it indexes many renowned journals in the field of business and management. The Social Science Citation Index and the Science Citation Index, which integrate the Web of Science database, are recognized as three of the most important indexes in the field of business and management. The following search argument was applied: ((triple bottom line) or (environmental performance; social performance; economic performance)).

The selection and analysis of articles was conducted in three steps. 1) In the initial sample, we screened for articles published in journals that are outlets for research of production and operations management and sustainability which were previously identified in works by Petersen, Aase, and Heiser (2011) Min and Kim (2012), Fry and Donohue (2013) and Linton (2013). 2) Later, article titles, keywords, and abstracts were analyzed, and the papers out of the scope of this review were removed. 3) We conducted a critical read- ing, analysis, and evaluation of each paper to check its methodological approach, unit of analysis, focus, findings, as well as the 3BL dimensions analyzed and whether the article emphasized a cross-national context. For the present study, we selected the publications with highest qualification, relevance, and importance to ensure the most adequate theoretical contextualization and consistent findings. Figure 1 summarizes the article search and selection strategy we adopted for the literature review.

Figure 1: Paper search and selection strategy.

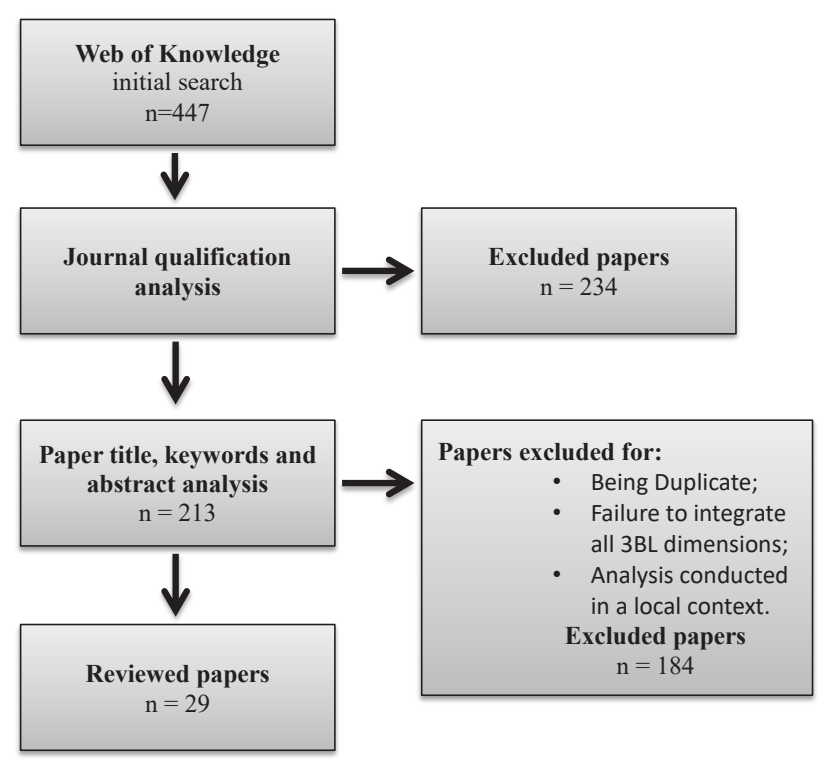

\section{RESULTS}

In this section, we summarize the literature that integrates 3BL dimensions into an international operations context. First, we present a profile of the final sample of articles, summarized in Exhibit 1, which provides information about the journals, year of publication, authors, the articles published in each journal, and the 2016 Journal Citation Report (JCR) Impact Factor. Second, we introduce the main drivers of and barriers to the adoption of triple bottom line practices by companies in an international context. Then, we examine the necessary social pressure and isomorphic change to integrate 3BL aspects into an international operations context, followed by an analysis of the legislation and political demands related to this integration process. Finally, we identify and examine the methodological approaches of the research included in our study. This analysis shows that the functionalist paradigm has provided the dominant framework in research about the interaction between economic, social and environmental performance in the context 
of international operations. It provides us with a clear picture of the level of analyses and the goals of these studies. Subsequently to this analysis, Exhibit 2 summarizes the main findings of the articles examined in the literature review.

\section{Sample Profile}

In our sample, 15 journals published the 29 papers identified. We found a concentration of works in relatively few journals, four of which accounting for $51.72 \%$ of all articles on 3BL and international operations in our sample. All articles were published after 2000. From 2010 onwards, we found an increase in the number of articles about 3BL in the international operations literature. The JCR Impact factor of these journal varies from 1.188 (IEEE Transactions on Engineering Management) to 7.268 (Management Information Systems Quarterly).

Figure 2 shows the country of the institutions authors are affiliated to. A total of 78 researchers in our sample have 16 articles with 3 or more sponsors. Carter published 3 articles, the highest number as there are no dominant authors in the field yet. The researchers work at institutions in 16 countries, with England and United States accounting for $40 \%$ of them.

Figure 2: Country of the institution the author is affiliated to.

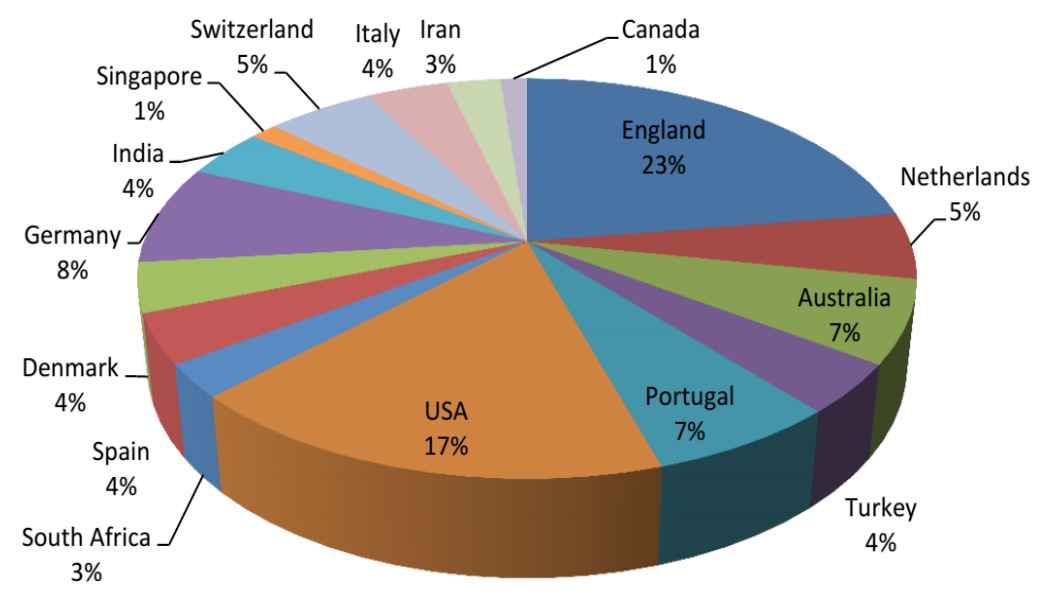

We also analyzed articles' methodological approach and unit of analysis, which are shown in Exhibit 1. More than half of the studies were empirical and used statistical analysis or case studies. As for the unit of analysis, $93.1 \%$ of our sample analyze a firm or a supply chain. From a value chain perspective, Fearne,
Martinez, and Dent (2012) present a literature review about the implications of the dimensions of sustainability to the analysis of value chain, while Giunipero, Hooker, and Denslow (2012) analyzed the drivers of and barriers to sustainable operations from a purchase and supply management perspective.

Exhibit 1: Journals and articles published about international operations management related to the Triple Bottom Line

\begin{tabular}{l|l|l}
\hline \multicolumn{1}{c|}{ Journals } & \multicolumn{1}{c|}{ Papers } & \multicolumn{1}{c}{$\begin{array}{c}\text { JCR Impact } \\
\text { Factor } 2016\end{array}$} \\
\hline $\begin{array}{l}\text { Business Strategy and the } \\
\text { Environment } \\
\text { Ecological Economics }\end{array}$ & $\begin{array}{l}\text { Birkin, F., Cashman, A., Koh, S. C. L., \& Liu, Z.(2009); Meehan \& Bryde } \\
(2011) ; \text { Al-Najjar \& Anfimiadou (2012). } \\
\text { Gerbens-Leenes, Moll, Schoot Uiterkamp (2003); Foran, B., Lenzen, M., } \\
\text { Dey, C., \& Bilek, M. (2005); Erol, Sencer \& Sari (2011). }\end{array}$ & 2.965 \\
\hline
\end{tabular}




\begin{tabular}{|c|c|c|}
\hline $\begin{array}{l}\text { IEEE Transactions on Engi- } \\
\text { neering Management } \\
\text { International Journal of } \\
\text { Operations \& Production } \\
\text { Management }\end{array}$ & $\begin{array}{l}\text { Azevedo, Carvalho, Duarte \& Cruz-Machado (2012) } \\
\text { Giovanni (2012). }\end{array}$ & $\begin{array}{l}1.188 \\
3.339\end{array}$ \\
\hline $\begin{array}{l}\text { International Journal of } \\
\text { Physical Distribution \& Logis- } \\
\text { tics Management } \\
\text { Journal of Cleaner Produc- } \\
\text { tion }\end{array}$ & $\begin{array}{l}\text { Carter \& Rogers (2008); Carter \& Easton (2011). } \\
\text { Labuschagne, C., Brent, A. C., \& van Erck, R. P. G.(2005); Frías-Aceituno, } \\
\text { J. V., Rodríguez-Ariza, L., \& García-Sánchez, I. M. (2013); Govindan, } \\
\text { Khodaverdi \& Jafarian (2013). }\end{array}$ & 2.577 \\
\hline $\begin{array}{l}\text { Journal of Operations Man- } \\
\text { agement } \\
\text { Journal of Purchasing and } \\
\text { Supply Management }\end{array}$ & $\begin{array}{l}\text { Wu \& Pagell (2011) } \\
\text { Schneider \& Wallenburg (2012); Giunipero, Hooker \& Denslow (2012). }\end{array}$ & $\begin{array}{l}5.207 \\
3.240\end{array}$ \\
\hline $\begin{array}{l}\text { Journal of Supply Chain } \\
\text { Management } \\
\text { Management Decision }\end{array}$ & $\begin{array}{l}\text { Tate, Ellram \& Kirchoff (2010); Reuter, Foerstl \& Blome (2010). } \\
\text { Goyal (2013) }\end{array}$ & $\begin{array}{l}5.789 \\
1.396\end{array}$ \\
\hline $\begin{array}{l}\text { Management Information } \\
\text { Systems Quarterly } \\
\text { Operations Research }\end{array}$ & $\begin{array}{l}\text { Melville (2010) } \\
\text { Chen \& Delmas (2012) }\end{array}$ & $\begin{array}{l}7.268 \\
1.779\end{array}$ \\
\hline $\begin{array}{l}\text { R \& D Management } \\
\text { Supply Chain Management - } \\
\text { An International Journal }\end{array}$ & $\begin{array}{l}\text { Paramanathan, S., Farrukh, C., Phaal, R., \& Probert, D. (2004) } \\
\text { Hamprecht et al. (2005); Vasileiou \& Morris (2006); Andersen \& Skjoett- } \\
\text { Larsen (2009); Fearne, Martinez, \& Dent (2012); Gualandris, Golini \& } \\
\text { Kalchschmidt (2014); Ortas, Moneva \& Álvarez (2014). }\end{array}$ & $\begin{array}{l}2.444 \\
4.072\end{array}$ \\
\hline $\begin{array}{l}\text { Transportation Research Part } \\
\text { E - Logistics and Transporta- } \\
\text { tion Review }\end{array}$ & Carter, C. R., Kale, R., \& Grimm, C. M. (2000) & 2.974 \\
\hline
\end{tabular}

Source: The authors' own elaboration from the literature review.

\section{Social Pressure and Isomorphic Change towards Integrating Triple Bottom Line Aspects}

Friedman (1970) proposed that while the social and environmental issues are important, they are incompatible with the corporate goal of generating profit. The emergence of an economic order based on technical and economic conditions of production created conditions for structural change to become less and less associated to competition or the need for efficiency, and more and more the result of isomorphic processes that arise from the structures of organizational fields (DiMaggio \& Powell, 1983). Once structured within an organizational field, bounded rationality drives firms to start reflecting on the successful cases of other companies, which leads them to adopt similar management and production practices. These successful practices become institutionalized in the field as a way of legitimizing organizational processes, even if they do not improve organizational performance. Thus, organizational structures seek to adapt to environmental conditions to gain legitimacy in the organizational field, competing not only for resources and customers, but also for political power and institutional legitimacy.

Azevedo et al. (2012) illustrate the case of automotive industry, where sustainable standards were deployed across most companies in the industry and required by suppliers. Social pressures for international companies to engage in social and environmental responsibility initiatives resulted in an isomorphic process. These companies have come 
to mirror business processes of other firms already engaged in initiatives - mimetic isomorphism -, to do what is professionally correct - normative isomorphism - or to comply with rules imposed by external forces - coercive isomorphism. Although the necessary investments to adapt operations to 3BL goals, as well as structural inertia, can be barriers to the adoption of sustainable strategies, isomorphism within the organizational field generates business opportunities that can create incentives for companies to adapt their production processes to integrate their economic goals to social and environmental aspects.

The literature provides different measurement and analysis models for evaluating companies' response to social pressures. Chen and Delmas (2012) identify critical flaws in traditional paradigms, and develop a new framework to measure eco-inefficiency from a firm-based perspective. From a supply chain perspective, Gerbens-Leenes, Moll and Schoot Uiterkamp (2003) design a method to measure environmental sustainability for food production systems. Foran et al. (2005) propose a framework based on input-output analysis to integrate sustainable chain management and reporting activities. They present a standardized system of national accounts that facilitates listing environmental effects in a global scenario. Labuschagne et al. (2005) present an operations sustainability evaluation model for the manufacturing sector. Carter and Rogers (2008) propose a framework to integrate supply chain management and 3BL, while Erol, Sencer, and Sari (2011) present a multi-criteria framework to evaluate and compare companies' performance in terms of sustainable supply chain. Govindan, Khodaverdi, and Jafarian (2013) propose a multi-criteria model for selecting suppliers in supply chains based on the 3BL approach.

Despite the attempts to evaluate sustainability from a 3BL perspective, these models emphasize the firm's financial aspects. This flaw is reflected on supply chain behaviors that seek to minimize the impacts of social and environmental events on their economic goals, thus leaving aside social and ecological concerns, which causes politicians and lawmakers to propose new regulatory standards to induce companies to adopt management practices aligned to 3BL goals.

\section{Legal and Political Demands for Integrat- ing Triple Bottom Line into Operations Management}

Because of the concerns with the environmental and social impacts of business activities, sustainability becomes more and more relevant in the lawmaking agendas of most governments, forcing politicians and governments to enhance the effectiveness of correlate policies (Hopkins et al., 2009).

Even in extremely liberal contexts, the state establishes general premises to organize and direct collective development actions. The culture of each society affects the adoption of sustainability policies by organizations and vice-versa. Social systems and standards express this culture, thus changing the internal and external conduct of the organization (Crilly, 2011; D. Matten \& Moon, 2008) and making the state a key player in developing behavioral patterns.

Firms adopt sustainable management practices as a response to an increasingly challenging regulatory environment. Thus, lawmaking becomes the sustainability-related issue with the greatest impact on businesses, due to the legal costs of escalating penalties and fines (Giunipero, Hooker, \& Denslow, 2012). In line with institutional theory, Campbel (2006) argues that companies are most likely to act in a responsible way when they operate in an institutional context with coercive and normative pressure. This approach considers that a well-developed legal system exists to protect stakeholders interests, while recognizing that normative institutions can vary across countries, affecting corporate behavior in different ways.

Frías-Aceituno et al. (2013) compare the common law and civil law systems in the various countries, as well as the efficiency and effectiveness of the mechanisms used to enforce the recommendations and regulations in effect. Civil law is a more stakeholderoriented system than common law in that it regards firms as autonomous economic entities formed by a coalition of stakeholders.

Influenced by this stakeholder coalition, companies in civil law countries - and countries where law and order indicators are high - are more likely to disclose information on their environmental management practices. However, the presence of many approaches to sustainability means that managers have different perceptions of what sustainability is, which leads companies to emphasize distinct aspects of social, environmental and economic responsibility, depending on their size and geographical location (Carter \& Rogers, 2008; Tate, Ellram, \& Kirchoff, 2010). 
The regulatory environment is not the only inducer of sustainable behaviors. In terms of politics, companies are also subject to pressure by the society they operate in. This pressure derives from the company's heavy presence in certain locations sometimes replacing the state itself - and its desire to legitimize its actions. There are power relations through which organizations can create a domination and dependence environment which, on the one hand, makes way for their social integration, and on the other, forces them to adopt practices of popular interest that are not always profitable to the organization (Dirk Matten \& Crane, 2005; Scherer \& Palazzo, 2007).

In their analysis of a sample of Italian and American multinational companies, Giovanni (2012) and Hooker and Denslow (2012), describe the main difficulties to adopt sustainable practices. The main barriers cocern the resources available for investments in the environmental area, as well as companies' emphasis on different facets of the 3BL dimensions, both upstream and downstream the supply chain, according to industry, size, and geographic location. On the other hand, compliance with legal requirements, institutional pressure, and initiatives by executives to improve organizational performance are the main driving forces behind the development of sustainable operations and the disclosure of social and environmental impacts.

\section{A Functionalist Perspective on the Triple Bottom Line Literature}

The functionalist paradigm has provided the dominant framework in research about the interaction between economic, social, and environmental performance in the context of international operations. Despite the greater importance given to social and environmental practices, the main concern of companies is related to market and economic factors (Vasileiou \& Morris, 2006). Fearne, Martinez, and Dent (2012) show that most businesses are focused on economic sustainability, and pay little attention to the social and environmental consequences of their production processes. They ignore the competitive advantages achieved by developing practices that can mitigate the environmental impact of production activities and improve stakeholders' well-being.

In their analysis of the chemical industry, Reuter et al. (2010) describe how the purchasing and supply management function can integrate sustainability aspects into its global supplier management process. Their findings show that first movers obtain advantages through an early evaluation of suppliers, resulting in accumulation of sustainability-related capabilities compared to competitors and their production practices. The structure of sustainable global supplier management processes does not depend on perceived stakeholder pressure or the sustainability content covered by global supplier management.

Wu and Pagell (2011) examine the supply chains of eight leading companies in terms of sustainable business practices in the United States to determine how these companies balance profitability and environmental sustainability in a context of uncertainty. The authors found that managers often lack sufficient information in making environmental decisions. Factors such as uncertainty about environmental outcomes and future regulations are among the causes of uncertain decisions, driving companies to adopt operating principles and technical standards to mitigate such information uncertainty.

To avoid these information asymmetries, information and technology must be disseminated throughout the supply chain to create control mechanisms that can foster responsible practices (Hamprecht, Corsten, Noll, \& Meier, 2005; Paramanathan, Farrukh, Phaal, \& Probert, 2004). Andersen and SkjoettLarsen (2009) suggest that incentives for suppliers to act responsibly include employee training, experience sharing, the training of key personnel, longterm contracts and larger purchase orders. However, little is known about the drivers of and barriers to the adoption of sustainable practices by firms or how they can effectively extend their control over suppliers' 3BL practices (Giunipero et al., 2012).

The articles that take a firm-based perspective analyze the relationship between sustainable practices and firm performance (Carter, Kale, \& Grimm, 2000; Goyal, Rahman, \& Kazmi, 2013), the process of implementing sustainable sourcing (Schneider \& Wallenburg, 2012), and the role of informational systems in improving sustainable performance (Melville, 2010). Other papers evaluate the influence of sustainable practices on firm stock value (Al-Najjar \& Anfimiadou, 2012), the drivers of and barriers to sustainable practices (Birkin, Cashman, Koh, \& Liu, 2009), and the impact of legal systems on the preparation and publication of integrated sustainability reports (Frías-Aceituno et al., 2013). 
Studies that examine the influence of social and environmental practices on firm operations' financial performance demonstrate that environmentally and socially efficient firms have better financial performances and higher market values than those lacking environmental practices (Al-Najjar \& Anfimiadou, 2012; Carter et al., 2000), although results can vary according to industry and local cultural and economic conditions (Goyal et al., 2013; Ortas, Moneva, \& Álvarez, 2014). These distinct contexts can drive companies to develop integrated sustainability reports in order to get a coherent overview of the available information about strategy, governance, performance and future perspectives, thus reflecting the economic, cultural and social differences between the markets they operate in (Frías-Aceituno et al., 2013).

Gualandris, Golini, and Kalchschmidt (2014) show that although global sourcing primarily aims to reduce globalization's negative impacts, global companies get no direct benefit from sustainable supply management. However, they can achieve high levels of sustainability performance. Firms that look for opportunities outside their own region may leverage their learning curve and thus obtain more benefits from a sustainable supply chain. When the degree of environmental regulatory complexity increases, the first mover in pollution prevention has a competitive advantage due to the learning curve generated, which helps companies acquire/develop rare and valuable resources/capabilities.

In their analysis of how the food industry monitors suppliers' 3BL performance, Hamprecht et al. (2005) argue that adopting a business-to-business perspective can facilitate the control over the supply chain. Andersen and Skjoett-Larsen (2009) analyze how a Swedish company implements and manages sustainable practices at their suppliers, showing that company size, image, and reputation are key factors to successfully implementing a sustainable supply chain.

In order to evaluate the influence of social and environmental aspects of the economic performance of companies, a series of articles seek to identify and understand the financial barriers to companies' investments in sustainability programs. Birkin et al. (2009) analyzed sustainable practices in China from the perspective of local firms, while Tate, Ellram, and Kirchoff (2010) analyzed the corporate communication of 100 socially and environmentally responsible global companies to determine how supply chain strategies can influence 3BL.

Exhibit 2: Articles on Operations Management related to Triple Bottom Line

\begin{tabular}{l|l|l|l}
\hline \multicolumn{1}{c|}{ Article } & \multicolumn{1}{c|}{ Method } & Unit of analysis & \multicolumn{1}{c}{ Research Findings } \\
\hline Carter et al. (2000) & Empirical & Firm & $\begin{array}{l}\text { Environmental purchasing activities have a positive impact on } \\
\text { firm performance. }\end{array}$ \\
\hline $\begin{array}{l}\text { Gerbens-Leenes, Moll, } \\
\text { (2003) }\end{array}$ & Analytical & Supply Chain & $\begin{array}{l}\text { Companies have direct responsibility for the effects of their } \\
\text { operations and share responsibility for chain-related effects. } \\
\text { Environmental reporting is still poorly developed, evaluating } \\
\text { environmental effects at a local level. Reports using widely } \\
\text { accepted standards are not available, resulting in conflicting } \\
\text { information that fails to address sustainability in a cross- } \\
\text { national context. }\end{array}$ \\
$\begin{array}{l}\text { Paramanathan et al. } \\
\text { (2004) }\end{array}$ & Conceptual & Supply Chain & $\begin{array}{l}\text { Effective technology management and strategy require } \\
\text { companies to adopt a perspective of future developments in } \\
\text { the business environment to facilitate long-term planning. }\end{array}$ \\
\hline $\begin{array}{l}\text { Labuschagne et. al. } \\
\text { (2005) }\end{array}$ & Empirical & Firm & $\begin{array}{l}\text { The indicators proposed to measure corporate sustainability } \\
\text { at a global level are ineffective to cover 3BL aspects at the } \\
\text { operational level. For example, the existing indicators do not } \\
\text { include most social issues affected by operations managers' } \\
\text { decisions. }\end{array}$ \\
\hline
\end{tabular}




\begin{tabular}{|c|c|c|c|}
\hline Article & Method & Unit of analysis & Research Findings \\
\hline $\begin{array}{l}\text { Hamprecht et al. } \\
\text { (2005) }\end{array}$ & Case Study & Firm & $\begin{array}{l}\text { Controlling the sustainability of suppliers means controlling } \\
\text { the supply chain's economic, social and environmental } \\
\text { performance. However, little is known about how companies } \\
\text { can efficiently extend their existing supply chain control to } \\
\text { cover these aspects. }\end{array}$ \\
\hline Foran et. al. (2005) & Analytical & Supply Chain & $\begin{array}{l}\text { The lack of data integration and an internationally accepted } \\
\text { environmental accountability system make it difficult to } \\
\text { quantify the effects on the production chains when they } \\
\text { source from a wide range of countries. }\end{array}$ \\
\hline $\begin{array}{l}\text { Vasileiou \& Morris } \\
\text { (2006) }\end{array}$ & Empirical & Supply Chain & $\begin{array}{l}\text { The dominant concern in supply chains are economic } \\
\text { and market factors related to maintaining a competitive } \\
\text { advantage. However, social and environmental factors are } \\
\text { beginning to gain greater relevance. }\end{array}$ \\
\hline Carter \& Rogers (2008) & $\begin{array}{l}\text { Literature } \\
\text { review }\end{array}$ & Supply Chain & $\begin{array}{l}\text { Different approaches to sustainability cause managers to } \\
\text { have discrepant viewpoints on what sustainability is }\end{array}$ \\
\hline Birkin et al. (2009) & Empirical & Firm & $\begin{array}{l}\text { Despite the lack of development in sustainable practices, } \\
\text { small and medium Chinese companies have become } \\
\text { increasingly concerned with improving environmental and } \\
\text { socially responsible actions. }\end{array}$ \\
\hline $\begin{array}{l}\text { Andersen \& Skjoett- } \\
\text { Larsen (2009) }\end{array}$ & Case study & Supply Chain & $\begin{array}{l}\text { Multinational corporations are responsible for environmental } \\
\text { and social practices in the entire organization, including } \\
\text { their suppliers and the entire supply chain. Information } \\
\text { and technology need to be disseminated throughout the } \\
\text { supply chain. Therefore, the company needs to create control } \\
\text { mechanisms for responsible practices in the supply chain. }\end{array}$ \\
\hline Melville (2010) & Analytical & Firm & $\begin{array}{l}\text { Information systems are an important but misunderstood } \\
\text { instrument of organizational environmental sustainability as } \\
\text { they enable new practices and processes that support the } \\
\text { formation of beliefs and actions and the assessment of results. }\end{array}$ \\
\hline $\begin{array}{l}\text { Tate, Ellram \& Kirchoff } \\
\text { (2010) }\end{array}$ & Analytical & Supply Chain & $\begin{array}{l}\text { Companies emphasize different facets of social, } \\
\text { environmental, and economic responsibility upstream and } \\
\text { downstream in supply chains, based on industry, size and } \\
\text { geographic location. }\end{array}$ \\
\hline $\begin{array}{l}\text { Reuter, Foerstl \& Blome } \\
\text { (2010) }\end{array}$ & Case Study & Supply Chain & $\begin{array}{l}\text { Sustainable global supplier management capabilities are a } \\
\text { source of competitive advantage. } \\
\text { These capabilities are path-dependent and particularly } \\
\text { valuable when organizations are receptive to external } \\
\text { stakeholder pressure. Early movers reap competitive benefits } \\
\text { to a notable extend because of resource accumulation and } \\
\text { learning processes over time. }\end{array}$ \\
\hline
\end{tabular}




\begin{tabular}{|c|c|c|c|}
\hline Article & Method & Unit of analysis & Research Findings \\
\hline Wu \& Pagell (2011) & Case Study & Supply Chain & $\begin{array}{l}\text { Environmental decisions have a profound impact on a wide } \\
\text { range of supply chain issues and organizations' ability to } \\
\text { compete. } \\
\text { The paper found a sequence of decisions that, over } \\
\text { time, enabled organizations to create economically and } \\
\text { environmentally viable supply chains. The set of decisions } \\
\text { provides managers with a template to examine their strategic } \\
\text { options and create sustainable business models. }\end{array}$ \\
\hline $\begin{array}{l}\text { Meehan \& Bryde } \\
\text { (2011) }\end{array}$ & Empirical & Supply Chain & $\begin{array}{l}\text { Structural inertia creates barriers to adopting responsible } \\
\text { purchasing. Supplier engagement strategies could solve } \\
\text { this problem by shifting from enforcement and compliance } \\
\text { actions to developmental and collaborative actions with } \\
\text { suppliers. }\end{array}$ \\
\hline $\begin{array}{l}\text { Erol, Sencer \& Sari } \\
(2011)\end{array}$ & Empirical & Supply Chain & $\begin{array}{l}\text { The paper proposes a multi-criteria model to evaluate and } \\
\text { compare supply chains' sustainability performance. }\end{array}$ \\
\hline Carter \& Easton (2011) & $\begin{array}{l}\text { Literature } \\
\text { Review }\end{array}$ & Supply Chain & $\begin{array}{l}\text { The field of sustainable supply chain management has } \\
\text { evolved from a perspective of standalone research in social } \\
\text { and environmental areas to a corporate social responsibility } \\
\text { perspective, to the beginning of a convergence of } \\
\text { sustainability perspectives such as the triple bottom line and } \\
\text { the emergence of sustainable supply chain management as a } \\
\text { theoretical framework. }\end{array}$ \\
\hline $\begin{array}{l}\text { Al-Najjar \& Anfimiadou } \\
(2012)\end{array}$ & Empirical & Firm & $\begin{array}{l}\text { Environmentally efficient firms have higher market values } \\
\text { than those lacking environmental strategies. Involvement in } \\
\text { environmental policies has a positive impact on firm value. }\end{array}$ \\
\hline Giovanni (2012) & Empirical & Firm & $\begin{array}{l}\text { The environmental manager is a successful driver on triple } \\
\text { bottom line. This manager improves environmental and social } \\
\text { performance but contributes only indirectly to the economic } \\
\text { bottom line. }\end{array}$ \\
\hline $\begin{array}{l}\text { Schneider \& } \\
\text { Wallenburg (2012) }\end{array}$ & Conceptual & Firm & $\begin{array}{l}\text { Purchasing can recognize the status quo of sustainable } \\
\text { sourcing profiles compared to other profile types, and can } \\
\text { further decide future goals for implementing sustainable } \\
\text { sourcing in the mid and long term. Previous research stresses } \\
\text { the importance of stakeholder management but does not } \\
\text { show the relevant stakeholders. To implement sustainable } \\
\text { sourcing, purchasing should cooperate with other business } \\
\text { functions such as marketing and sales. }\end{array}$ \\
\hline Chen \& Delmas (2012) & Empirical & Firm & $\begin{array}{l}\text { The paper found critical flaws in the models of evaluation } \\
\text { of existing sustainable practices, showing that they can } \\
\text { present an eco-inefficient company as eco-efficient. From } \\
\text { these failures, it proposes a model eco-inefficiency in order to } \\
\text { correct these flaws. }\end{array}$ \\
\hline $\begin{array}{l}\text { Fearne, Martinez \& } \\
\text { Dent (2012) }\end{array}$ & $\begin{array}{l}\text { Literature } \\
\text { Review }\end{array}$ & Value Chain & $\begin{array}{l}\text { Value chain has focused on economic sustainability and paid } \\
\text { little attention to the social and environmental consequences } \\
\text { of firm impacts, thus ignoring the competitive advantages of } \\
\text { improving environmental management and social welfare. }\end{array}$ \\
\hline
\end{tabular}




\begin{tabular}{|c|c|c|c|}
\hline Article & Method & Unit of analysis & Research Findings \\
\hline $\begin{array}{l}\text { Giunipero, Hooker \& } \\
\text { Denslow (2012) }\end{array}$ & Empirical & $\begin{array}{l}\text { Purchasing } \\
\text { and supply } \\
\text { management }\end{array}$ & $\begin{array}{l}\text { Top management initiatives and government regulations } \\
\text { normally drive purchasing and supply management } \\
\text { sustainability efforts while investments in sustainability and } \\
\text { economic uncertainty are a hindrance to these programs. }\end{array}$ \\
\hline $\begin{array}{l}\text { Frias-Aceituno et al. } \\
\text { (2013) }\end{array}$ & Exploratory & Firm & $\begin{array}{l}\text { Companies in civil law countries and in countries with } \\
\text { high law and order indicators are more likely to disclose } \\
\text { information on their environmental management practices }\end{array}$ \\
\hline $\begin{array}{l}\text { Azevedo, Carvalho, } \\
\text { Duarte \& Cruz- } \\
\text { Machado (2012) }\end{array}$ & Case Study & Supply Chain & $\begin{array}{l}\text { The use of green purchasing guidelines, as well as } \\
\text { sourcing from environmentally responsible sources, can } \\
\text { reduce corruption risk, thus enabling synergies between } \\
\text { environmental and social standards and management } \\
\text { systems that can be used to monitor suppliers. This can } \\
\text { provide systems of early warning, timely recognition and } \\
\text { prevention of environmental and social irregularities in the } \\
\text { supply chain. }\end{array}$ \\
\hline Goyal (2013) & $\begin{array}{l}\text { Literature } \\
\text { review }\end{array}$ & Firm & $\begin{array}{l}\text { Research in the field of sustainability performance in relation } \\
\text { to firm performance analyzed this relationship in developed } \\
\text { countries. Results differ in various cultural and economic } \\
\text { contexts, and there is no universally accepted direction on } \\
\text { this relationship. Most studies use economic performance as a } \\
\text { proxy for firm performance. }\end{array}$ \\
\hline $\begin{array}{l}\text { Govindan, Khodaverdi } \\
\text { \& Jafarian (2013) }\end{array}$ & Empirical & Supply chain & $\begin{array}{l}\text { Proposes a multi-criteria approach to the selection of } \\
\text { suppliers in supply chains based on } 3 B L \text { premises. }\end{array}$ \\
\hline $\begin{array}{l}\text { Gualandris, Golini \& } \\
\text { Kalchschmidt (2014) }\end{array}$ & Empirical & Supply chain & $\begin{array}{l}\text { Global companies do not reap any environmental or social } \\
\text { benefit directly from supply management. When the degree } \\
\text { of environmental regulatory complexity increases, the first } \\
\text { mover in pollution prevention has a competitive advantage } \\
\text { due to the learning curve generated, which helps companies } \\
\text { acquire rare and valuable resources/capabilities }\end{array}$ \\
\hline $\begin{array}{l}\text { Ortas, Moneva \& } \\
\text { Álvarez (2014) }\end{array}$ & Empirical & Supply chain & $\begin{array}{l}\text { A wide diversity of patterns of relationship between } \\
\text { sustainable supply chain performance and economic } \\
\text { performance emerges when different geographical regions } \\
\text { and industries are considered. The relationship between these } \\
\text { constructs can be altered by the economic scenario. }\end{array}$ \\
\hline
\end{tabular}

Source: The authors' own elaboration from the literature review

\section{Conclusions and Directions for Further Research}

This article aims to present a literature review in order to analyze how the literature on international operations treats Elkington's 3BL dimensions. We identify the main drivers of and barriers to the adoption of 3BL practices by companies in an international context, and analyze how the demand for integrating 3BL goals has influenced participants' global supply chains with regard to management and relationships.

When Elkington (1997) proposed the concept of 3BL, he sought a way to harmonize the economic, environmental and social goals of business activities, recognizing that while these affect the environment and society, they can also generate economic benefits and competitive advantages. Despite assuming a balance between the economic, social and environ- 
mental aspects, studies on operations management with this approach to production chain sustainability often take a functionalist perspective. These studies are interested in providing rational explanations to social phenomena, so as to understand society in a way that can generate applied knowledge. They are intersted in "win-win" relationships that can maximize returns to shareholders, and consider investments in sustainability as an actual bilateral bonus relationship (Burrell \& Morgan, 1979). In so doing, even while they propose many social and environmental management reports, they seek to evaluate the influence of social and ecological aspects of firms' financial performance, putting aside the impact of productive processes on local communities and the environment.

Models that propose to evaluate sustainability from a 3BL perspective take into account different aspects of the construct, which prevents the emergence of a universally accepted standard and results in conflicting information that hinders 3BL analysis in a transnational context. Moreover, these models focus on local contexts, i.e., they reflect the concerns of developed countries about the social and environmental issues, while disregarding cultural, social and ecological trade-offs, as well as developing countries' demands about the social an environmental impacts of global supply chains. This disregard for local communities and the different concepts of what sustainability is hampers the operationalization of the construct, thus leading to the proposition of social and environmental responsibility programs with assumptions that favor the company's financial aspects. In the context of international operations, as the components of production chains are spread over different countries with distinct economic, environmental and social demands, it is imperative to propose operational standards that can balance these differences while enabling the analysis of the impact of productive activities on the environment and society in a global context. Further studies could focus on finding ways to balance 3BL goals in an operational context, as well as differences between countries, enabling the development of an internationally accepted standard.

Given the risk of ecological damage and exploitative labor practices in global supply chains, sustainability gains prominence on the public debate, forcing companies to improve their labor and environmental practices and putting governments under pressure to establish new environmental and labor regulations, as well as improve the effectiveness of existing policies. However, the focus on financial aspects of international operations pushes the social and ecological aspects to the background, creating incentives for opportunistic behavior. Companies can allocate offshore activities where environmental and social regulations are not enforced, thus threatening the environment and, particularly in developing countries, local communities' ability to improve their standards of living and benefit from the growth of economic activity. Research efforts directed to comparing different institutional environments also deserve further attention. Identifying behavior differences between spin-offs in countries with different legal environments is an initiative that can generate developments from the perspective of institutional theory. There are also efforts that can drive institutions to press companies into changing their standards through regulation and enforcement. There is room for progress in studies that seek to analyze companies' relationships in their international experience and multiinstitutional relations.

Finally, companies' domestic issues deserve attention in future research. Several features can be identified as enabling the adoption of sustainable behaviors by organizations, but others still need further analysis. Social pressure is recognized as capable of inducing companies towards certain conducts due to its power to legitimize corporate behaviors. This legitimacy, however, is to be achieved after a relationship has been developed between businesses and society. During this construction, can different levels of relationship cause different forms of sustainable behavior on the part of companies? Is their degree of integration into the community a factor that can shape their behavior? Such questions are challenges to advances in the field.

\section{REFERENCES}

Al-Najjar, B., \& Anfimiadou, A. (2012). Environmental policies and firm value. Business Strategy and the Environment, 21(1), 49-59. doi:10.1002/bse.713

Andersen, M., \& Skjoett-Larsen, T. (2009). Corporate social responsibility in global supply chains. Supply Chain Management: An International Journal, 14(2), 75-86. doi:10.1108/13598540910941948

Azevedo, S. G., Carvalho, H., Duarte, S., \& Cruz-Machado, V. (2012). Influence of green and lean upstream supply chain management practices on business sustainability. IEEE 
Transactions on Engineering Management, 59(4), 753-765. doi:10.1109/TEM.2012.2189108

Birkin, F., Cashman, A., Koh, S. C. L., \& Liu, Z. (2009). New sustainable business models in China. Business Strategy and the Environment, 18(February 2007), 64-77.

Burrell, G., \& Morgan, G. (1979). Sociological paradigms and organisational analysis. London: Heinemann.

Campbell, J. L. (2006). Institutional analysis and the paradox of corporate social responsibility. American Behavioral Scientist, 49(7), 925-938. doi:10.1177/0002764205285172

Carter, C. R., \& Easton, P. L. (2011). Sustainable supply chain management: Evolution and future directions. International Journal of Physical Distribution \& Logistics Management, 41(1), 46-62. https://doi. org/10.1108/09600031111101420

Carter, C. R., Kale, R., \& Grimm, C. M. (2000). Environmental purchasing and firm performance: An empirical investigation. Transportation Research Part E: Logistics and Transportation Review, 36, 219-228.

Carter, C. R., \& Rogers, D. S. (2008). A framework of sustainable supply chain management: Moving toward new theory. International Journal of Physical Distribution \& Logistics Management, 38(5), 360-387. doi:10.1108/09600030810882816

Chen, C.-M., \& Delmas, M. a. (2012). Measuring eco-inefficiency: A new frontier approach. Operations Research, 60(5), 1064-1079. doi:10.1287/opre.1120.1094

Crilly, D. (2011). Predicting stakeholder orientation in the multinational enterprise: A mid-range theory. Journal of International Business Studies, 42(5), 694-717. doi:10.1057/ jibs.2010.57

DiMaggio, P., \& Powell, W. (1983). The iron cage revisited: Institutional isomorphism and collective rationality in organizational fields. American Sociological Review, 48(2), 147160.

Dyllick, T., \& Hockerts, K. (2002). Beyond the business case for corporate sustainability. Business Strategy and the Environment, 11, 130-141.

Egri, C. P., \& Ralston, D. A. (2008). Corporate responsibility: A review of international management research from 1998 to 2007. Journal of International Management, 14(4), 319339. doi:10.1016/j.intman.2007.09.003

Elkington, J. (1997). Cannibals with Forks: The triple bottom line of 21st Century Business. UK: Capstone.

Erol, I., Sencer, S., \& Sari, R. (2011). A new fuzzy multi-criteria framework for measuring sustainability performance of a supply chain. Ecological Economics, 70(6), 1088-1100. doi:10.1016/j.ecolecon.2011.01.001

Fearne, A., Martinez, M. G., \& Dent, B. (2012). Dimensions of sustainable value chains: Implications for value chain analysis. Supply Chain Management: An International Journal, 17(6), 575-581. doi:10.1108/13598541211269193
Ferrer, G. (2008). Sustainability: What does it mean for the operations manager? Journal of Operations and Supply Chain Management, 1(2), 1-16.

Foran, B., Lenzen, M., Dey, C., \& Bilek, M. (2005). Integrating sustainable chain management with triple bottom line accounting. Ecological Economics, 52(2), 143-157. doi:10.1016/j.ecolecon.2004.06.024

Frías-Aceituno, J. V., Rodríguez-Ariza, L., \& García-Sánchez, I. M. (2013). Is integrated reporting determined by a country's legal system? An exploratory study. Journal of Cleaner Production, 44, 45-55. doi:10.1016/j.jclepro.2012.12.006

Friedman, M. (1970). The social responsibility of business is to increase its profi ts. New York Times Magazine, 17.

Gavronski, I. (2012). Resources and capabilities for sustainable operations strategy. Journal of Operations and Supply Chain Management, 5(Special Issue on Sustainability), 1-20. doi:10.12660/joscmv1n1p1-20

Gerbens-Leenes, P., Moll, H., \& Schoot Uiterkamp, a. J. (2003). Design and development of a measuring method for environmental sustainability in food production systems. Ecological Economics, 46(2), 231-248. doi:10.1016/S09218009(03)00140-X

Giovanni, P. de. (2012). Do internal and external environmental management contribute to the triple bottom line? International Journal of Operations \& Production Management, 32(3), 265-290. doi:10.1108/01443571211212574

Giunipero, L. C., Hooker, R. E., \& Denslow, D. (2012). Purchasing and supply management sustainability: Drivers and barriers. Journal of Purchasing and Supply Management, 18(4), 258-269. doi:10.1016/j.pursup.2012.06.003

Govindan, K., Khodaverdi, R., \& Jafarian, A. (2013). A fuzzy multi criteria approach for measuring sustainability performance of a supplier based on triple bottom line approach. Journal of Cleaner Production, 47, 345-354. doi:10.1016/j. jclepro.2012.04.014

Goyal, P. (2013). Corporate sustainability performance and firm performance research: Literature review and future research agenda. Management Decision, 51(2), 361-379. doi:10.1108/00251741311301867

Goyal, P., Rahman, Z., \& Kazmi, A. A. (2013). Corporate sustainability performance and firm performance research literature review and future research agenda. Management $D e-$ cision, 51(2), 361-379. doi:10.1108/00251741311301867

Gualandris, J., Golini, R., \& Kalchschmidt, M. (2014). Do supply management and global sourcing matter for firm sustainability performance?: An international study. Supply Chain Management: An International Journal, 19(3), 258274. doi:10.1108/SCM-11-2013-0430

Hamprecht, J., Corsten, D., Noll, M., \& Meier, E. (2005). Controlling the sustainability of food supply chains. Supply Chain Management: An International Journal, 10(1), 7-10. doi:10.1108/13598540510578315

Hopkins, M. S., Townend, A., Khayat, Z., Balagopal, B., Reeves, M., \& Berns, M. (2009). The business of sustainability: 
What it means to managers now. MIT Sloan Management Review, 51(1), 20-26. Retrieved from https://sloanreview. mit.edu/

Hubbard, G. (2009). Measuring organizational performance: Beyond the triple bottom line. Business Strategy and the Environment, 191(December 2006), 177-191. doi:10.1002/ bse

Khalid, R. U., Seuring, S., Beske, P., Land, A., Yawar, S. A., \& Wagner, R. (2015). Putting sustainable supply chain management into base of the pyramid research. Supply Chain Management: An International Journal, 20(6), 681-696. / doi.org:10.1108/SCM-06-2015-0214

Kleindorfer, P. R., Singhal, K., \& Wassenhove, L. N. Van. (2005). Sustainable operations management. Production and Operations Management, 14(4), 482-492.

Labuschagne, C., Brent, A. C., \& van Erck, R. P. G. (2005). Assessing the sustainability performances of industries. Journal of Cleaner Production, 13(4), 373-385. doi:10.1016/j. jclepro.2003.10.007

Matten, D., \& Crane, A. (2005). Corporate citizenship: Toward an extended theoretical conceptualization. Academy of Management Review, 30(1), 166-179.

Matten, D., \& Moon, J. (2008). "Implicit" and "explicit" CSR: A conceptual framework for a comparative understanding of corporate social responsibility. Academy of Management Review. doi:10.5465/AMR.2008.31193458

Meehan, J., \& Bryde, D. (2011). Sustainable procurement practice. Business Strategy and the Environment, 20(May 2010), 94-106.

Melville, N. (2010). Information systems innovation for environmental sustainability. Management Information Systems Quarterly, 34(1), 1-21.

Norman, W., \& MacDonald, C. (2004). Getting to the bottom of "triple bottom line." Business Ethics Quarterly, 14(2), 243-262.

Ortas, E., Moneva, J. M., \& Álvarez, I. (2014). Sustainable supply chain and company performance. A global examination. Supply Chain Management: An International Journal, 19(3), 332-350. doi:10.1108/SCM-12-2013-0444

Paramanathan, S., Farrukh, C., Phaal, R., \& Probert, D. (2004). Implementing industrial sustainability: The research issues in technology management. $R$ and D Management, 34(5), 527-537. doi.org/10.1111/j.1467-9310.2004.00360.x

Pisani, N., Kourula, A., Kolk, A., \& Meijer, R. (2017). How global is international CSR research? Insights and recommendations from a systematic review. Journal of World Business, (May), 1-24. doi:10.1016/j.jwb.2017.05.003

Reuter, C., Foerstl, K. A. I., \& Blome, C. (2010). Sustainable global supplier management: The role of dynamic capabilities in achieving competitive advantage. Journal of Supply Chain Management, 46(2), 45-63.

Scherer, A. G., \& Palazzo, G. (2007). Toward a political conception of corporate responsibility: Business and society seen from a habermasian perspective. Academy of Management Review_32(4), 1096-1120.

Schneider, L., \& Wallenburg, C. M. (2012). Implementing sustainable sourcing: Does purchasing need to change? Journal of Purchasing and Supply Management, 18(4), 243-257. doi:10.1016/j.pursup.2012.03.002

Seuring, S., \& Gold, S. (2012). Conducting content analysis based literature reviews in supply chain management. Supply Chain Management: An International Journal, 17(5), 544555. doi:10.1108/13598541211258609

Tate, W. L., Ellram, L. M., \& Kirchoff, J. O. N. F. (2010). Corporate social responsibility reports: A thematic analysis related to supply chain management. Journal of Supply Chain Management, 46(1), 19-44.

Tranfield, D., Denyer, D., \& Smart, P. (2003). Towards a methodology for developing evidence-informed management knowledge by means of systematic review. British Journal of Management, 14, 207-222. doi:10.1111/1467-8551.00375

Vasileiou, K., \& Morris, J. (2006). The sustainability of the supply chain for fresh potatoes in Britain. Supply Chain Management: An International Journal, 11(4), 317-327. doi:10.1108/13598540610671761

Wagner, M. (2015). The link of environmental and economic performance: Drivers and limitations of sustainability integration. Journal of Business Research, 68(6), 1306-1317. doi:10.1016/j.jbusres.2014.11.051

Wu, Z., \& Pagell, M. (2011). Balancing priorities: Decisionmaking in sustainable supply chain management. Journal of Operations Management, 29(6), 577-590. doi:10.1016/j. jom.2010.10.001 